\title{
"The Worse You Behave, The More You Seem, to be Rewarded": Bullying in Nursing as Organizational Corruption
}

\author{
Marie Hutchinson • Margaret H. Vickers • \\ Lesley Wilkes • Debra Jackson
}

Published online: 18 February 2009

(C) Springer Science + Business Media, LLC 2009

\begin{abstract}
This paper reports findings from the first, qualitative stage of a national sequential, mixed method study of bullying in the Australian nursing workplace. Twenty-six nurses who had experience of workplace bullying were recruited from two Australian public sector health care organizations. Examining the narrative data from the viewpoint of bullying being a corrupt activity we present an alternative perspective on group acts of bullying. By exploring bullying as corrupt behaviour, this paper challenges the assumption that bullying can be principally considered a series of isolated events stemming from interpersonal conflict, organizational pressures, or poor work design. Corruption in organizations has not previously been linked with or compared to bullying. In revealing the manner in which actors can engage in corrupt conduct that includes bullying, the findings from our study offer important implications for the management of workplace bullying as a serious and corrupt activity.
\end{abstract}

Key words bullying · mobbing · corruption · organizational behavior · workplace violence

\section{Bullying at Work}

In recent decades there has been growing interest in understanding hostile and harmful workplace behaviours such as bullying (Hutchinson et al. 2006a; O'Moore et al. 2003; Vickers 2006). There is considerable evidence that bullying involves repeated, demeaning or destructive acts resulting in harm to both individuals and institutions (Simpson and

\footnotetext{
M. Hutchinson $(\bowtie)$

Family and Community Health Research Group, College of Business, University of Western Sydney, C/-P.O. Box 148, Ballina, NSW 2478, Australia

e-mail: marie.hutchinson@scu.edu.au

M. H. Vickers

Family and Community Health Research Group, College of Business, University of Western Sydney, Locked Bag 1797, Penrith South DC, NSW 2067, Australia

L. Wilkes $\cdot$ D. Jackson

Family and Community Health Research Group, School of Nursing, College of Health \& Science, University of Western Sydney, Locked Bag 1797, Penrith South DC, NSW 2067, Australia
} 
Cohen 2004; Shields and Wilkins 2006; Stevenson et al. 2006). Exposure to bullying has been correlated with depression and anxiety (Kivimäkia and Virtanen 2003), withdrawal and avoidance at work (Hutchinson et al. 2008), career interruption and a reduced capacity to work (Chappell and Di Martino 2000; Hutchinson et al. 2008; McKay et al. 2008). While workplace bullying has attracted increasing attention the enabling or motivating factors explaining the behaviour are poorly understood.

We intend to demonstrate that bullying involving collusion between actors may also be framed as corrupt behaviour. By drawing attention to bullying as corrupt behaviour, we highlight a more disturbing side to the phenomenon. This, we hope, will enable organisations to realise the seriousness of bullying (and corruption) and be better informed on how they might deal with it, and respond to it, without trivialising the seriousness of what can take place. We commence with a discussion of current understandings of bullying before moving the discussion into the realm of what is known about corruption in organisations. Then, the research methodology is outlined before evidence of bullying as corruption is shared from the nursing workforce in Australia.

Conceptualized as a subset of aggression, workplace bullying is frequently described as a form of escalated conflict. From this perspective, emphasis is placed upon the traits of individuals targeted or motivating factors that may be present in an attempt to explain why individuals either become targets or engage in bullying behaviour. The resulting individualbased understandings suggest personality differences lead to conflict based power struggles, which escalate into bullying (Zapf and Einarsen 2003). This type of conceptualisation tends to reflect the perspectives of psychology and functional managerialism, and assumes that interpersonal conflict is responsible for the initiation of bullying (Salin 2003), and that the conduct can be simply resolved through policy formulation, preventative education and mediation.

Group acts of bullying have been identified as a common form of workplace abuse, often termed "mobbing" (Hubert and van Veldhoven 2001). Mobbing has been described as the process whereby a work group gangs up on a colleague in a form of displaced aggression or exaggerated conflict (Einarsen et al. 2003). While the concept of mobbing recognizes the role of work groups in bullying, there is a tendency when taking these approaches to view bullying as arising from the deviant behaviour of bullies who target an "accidental victim" (Einarsen 1999). However, there have been few studies examining the mechanisms that enable group acts of bullying.

An alternative perspective identifies organizational factors that precipitate and perpetuate bullying. These approaches have tended to identify bullying as arising from: deficiencies in work design (Leymann 1996; Salin 2003); excessive work pressure (O’Moore et al. 2003); and, organizational change and restructure (McCarthy et al. 1995; Hutchinson et al. 2006b). It is surmised that these factors lead to unavoidable pressures that encourage unwitting individuals to commit abusive acts. We claim that such arguments offer a limited perspective as to what might motivate bullying behaviour.

\section{Corruption in Organizations}

Deviant, dysfunctional, uncivil, and counterproductive organizational behaviours overlap somewhat with the notion of corruption (Ashforth et al. 2008). Corruption is a complex, multifaceted, and dynamic phenomenon, with no single definition able to adequately capture the complexity of the concept. What is considered corrupt conduct changes over time to reflect public, institutional, cultural and political attitudes (Luo 2002). Like bullying, there 
tends to be as many definitions of corruption as there are studies devoted to it, with most tending to indicate that it has something to do with the abuse of power and or money.

At the broadest level, corruption can be defined as a change of a thing from its naturally sound condition, to something impure, unsound, damaged, or bad (Bukovansky 2002). Corruption makes reference to behaviors and actions that are lacking in integrity, being open to dishonesty or disloyalty, and that may even be morally depraved and unclean. It implies a wilful perversion of trust and ideals (Ashforth and Anand 2003) through the pursuit of individual interests, enabled through the deliberate misuse of organizational resources, routines, or processes (Lange 2008). Accordingly, a defining feature of corruption is that it is motivated by gain (Luo 2002).

Legalistic understandings of corruption point to illegal activities (e.g. bribery, extortion, and fraud) but do not consider activities that may be legal, yet involve the misuse of legitimate authority, processes or resources for personal gain (Sissener 2001). While the pecuniary benefits derived from corruption are tangible, individuals may also gain in power and influence, as well as less tangible benefits, such as increased prestige, status, or political gain (Hindess 2004). Attempting to capture the complexity of corruption, Sissener (2001; citing Olivier de Sardan 1999: 27) used the term 'corruption complex' to include a broad range of practices such as nepotism, abuse of power, embezzlement, misappropriation, misuse of resources, influence peddling, prevarication, insider trading and abuse of the public purse.

Narrow definitions, such as those that focus purely upon the actions of individuals, or upon money and power abuse, fail to capture the complexity of corruption. To that end, we emphasise that, in general terms, corruption can also be considered a form of behaviour which involves the individual or institutional misuse of public resources or entrusted power, for private power, profit, or political gain, through conduct that deviates from formal rules (Lindgreen 2004). It can include: acts or omissions; the use or misuse of influence, position, or information; dishonest exercise of official power; and, the dereliction of duty. Importantly, this broader understanding of corruption focuses attention upon forms of everyday behaviour that may be overlooked within narrower economic or legalistic understandings. It also includes many acts that could be bullying such as: discrediting the professional reputation of an employee for personal gain; placing pressure upon actors to ensure they do not disclose unsafe products; and, threatening individuals who disclose collusive activity.

Corruption is known to affect the public, private and non-government sectors and is associated with the actions of individuals within organizations and organizations themselves (Ashforth and Anand 2003). Corruption in the public sector has included: the use of unofficial payments in the markets for health care in transition countries (Ensor 2004); judicial corruption and policy development (Lambsdorff 2002; Marjit and Shi 1998); as well as corruption by correctional officers (Dowden and Tellier 2004), the police force (McCormack 1996); educators (Heyneman 2004); and public health officials (Reich 2002; Afsana 2004; Ensor 2004). Within the publicly funded health sector, corruption has been identified to have serious detrimental effects upon patient safety and quality of care (Ibrahim and Majoor 2002). Unfortunately, investigations into the management of adverse events in the health care sector show that whistleblowers are usually dealt swift retaliation, and are often sanctioned by those in authority (Griffin 2005), making it difficult to identify and correct such situations.

Unlike studies of bullying, those focused on corruption have tended not to focus on the targets, but on the traits of perpetrators and the systems that enable corrupt activities to continue. For instance, when exploring the traits of corrupt individuals, it has been argued that economics students are significantly more corrupt than other students (Frank and Schulze 2000: 101). Those in management have been identified as being willing to tolerate 
unethical acts by their peers (Coleman and Ramos 1998; Pitt and Abratt 1986). Conversely, women have been found to be more trustworthy and public spirited, and more likely to promote honest government. By drawing attention to individual corrupt attributes, it has been suggested that corruption can be eliminated by rooting out renegade individuals (Misangyi et al. 2008), or reducing exposure to situations where individuals may disengage their moral reasoning (Bandura 2002).

From an organizational perspective, corruption has been explored as a system of normalized rules and transformed legal authority, cemented through cooperation and trust (Robbins 2000: 424; Lambsdorff 2002). Corrupt behaviours permeate both business processes and the attitudes of decision makers (Kriekebaum 2008) and can become entrenched in organizational roles, routines and practices through socialisation processes, reward systems, and rationalizing belief systems, which serve to institutionalize corrupt practices and activities (Misangyi et al. 2008). Through workplace learning, individuals and groups can be influenced to adopt unethical or antisocial behaviours as modelled by others (Robinson and O'Leary-Kelly 1998). When embedded within routines, corruption becomes less visible and normalized as part of how work gets done. In this way, corruption can be characterised as a dangerous contagion within organizations and able to spread across entire industries (Ashforth et al. 2008).

Employing the dimensions of beneficiary and collusion Pinto et al. (2008) have conceptualized two types of corruption at the organizational level. Considering the notion of beneficiary, they have suggested individuals may act solely for private benefit, or, the organization itself may be the beneficiary. Accordingly, when individuals co-operate together in a corrupt manner for the benefit of the organization this manifests a 'corrupt organization'. Alternatively, corruption between individuals that occurs for personal benefit manifests as an 'organization of corrupt individuals' (Pinto et al. 2008: 688). However, while these concepts provide an explanatory framework for collusion as a feature of corruption, there have been few studies investigating the mechanisms through which collusion between actors engaged in corruption occurs. Theoretical models of collusive relationships benefiting individuals identify wages and competitive labor markers as moderators of collusion (Chang and Lai 2002; Langbein and Jorstad 2004). These types of models provide little insight into the mechanisms or motivations for corruption, particularly in public sector organizations.

\section{Research Design}

Reported here are results from the first stage of a sequential, mixed method study (Cresswell et al. 2004). The first, qualitative, in-depth, phase involved semi-structured interviews exploring nurses' experiences of being bullied, as well as their beliefs and perceptions about bullying, and why it took place. Participants were recruited from two Australian health care organizations. Following approval from the human research and ethics committees of the participating institutions, recruitment occurred through fliers disseminated throughout the two organizations via staff notice boards, newsletters and staff pay slips.

Purposive sampling was used to select participants, with a small sample of respondents deliberately sought from each organization. Nurses who responded to the recruitment fliers were forwarded an information sheet containing details about the study, the ethics approval process, and a consent form. Following return of the signed consent form, interviews were arranged. Twenty-six nurses who had personal experience of workplace bullying were interviewed. Fourteen of the nurses interviewed held senior clinical positions and were involved in providing clinical leadership in their specialist field. In presenting information from 
participants considerable caution has been exercised to protect their identity, including the use of pseudonyms and limiting specific identifying contextual material from the analysis.

The interview data was recorded in its entirety, transcribed verbatim and analysed using the constant comparative method (Lincoln and Guba 1985) using the Nvivo software program. During the analysis, codes were attached to words, phrases and statements that revealed the detail of the experiences allowing for patterns to emerge (Miles and Hubermann 1994). An audit trail was maintained, with coding and memos undertaken on specific issues relating to the emerging thematic understanding. Throughout the process, a journal recording reflections, theoretical notes, and emerging understanding was maintained. The codes were clustered into categories and sub-categories to reduce their number and conceptualise emerging patterns. The final stage of the process was the development of thematic understanding from the categories, coded text, memos and reflective journal. Summarized here are five constituent categories from one emergent theme.

\section{Bullying as Organizational Corruption}

The findings of our research offer an alternative perspective on group acts of bullying. Reflecting upon their workplace experiences, participants described bullying, and the organizational systems and processes that perpetuated or condoned the behavior as unethical, corrupt or evil. Synthesising these sensemakings from the viewpoint of bullying as a corrupt activity, we are able to identify and vivify bullying as a form of conduct requiring cooperation among actors in a network.

Rather than accepting that organizational processes and pressures act as an "accidental trigger" for bullying by actors who may be "in over their heads", or that group acts of bullying are not premeditated, our respondents reported examples of bullies cooperating together to engage in conduct that included the misuse of both legitimate authority and institutional processes for personal gain. Relationships among actors facilitated a form of group bullying more extensive forms of premeditated group behavior than that previously reported as mobbing (see Leymann 1996). We suggest that, while individual differences or conflicts are likely to result in bullying as mobbing, when institutional processes serve to normalize and rationalize the behavior it can evolve and metastasize as corruption.

Presented here are five key aspects of bullying as organizational corruption: (1) silence and censorship: the institutional backdrop, which examines the institutional backdrop of secrecy and cover up in which corrupt conduct was able to flourish; (2) networks of predatory alliances, which details the long lasting nature of established informal networks between those who engaged in bullying as corrupt conduct; (3) corrupting legitimate routines and processes, which details how legitimate routines were corrupted within the alliances for personal gain; (4) reward and promotion, which describes the manner in which networks operated to advance the career prospects of individuals within the alliances; and, (5) protection from detection, which outlines the mechanisms through which alliances provided protection to actors. Through this discussion we aim to demonstrate how many hidden and poorly recognised acts of bullying can be considered corrupt practices and should be dealt with accordingly.

Silence and Censorship: The Institutional Backdrop

Bullying as corrupt conduct was reported to occur within a backdrop of institutionalised silence and censorship that provided the context where this form of bullying was able to 
flourish. Respondents revealed an organizational environment where, as a consequence of pressure to meet stakeholder demands, the "official" position was to routinely deny misconduct or adverse events, with disclosures framed as a threat to the cohesiveness and public image of the institution. As a consequence, opportunities were created for individuals to engage in unethical behaviour to protect the interests of the organization, and in so doing, further their own career progress.

Karen spoke of her daily work life in a busy Emergency Department in a hospital system unable to meet demand. Along with a number of her colleagues, she had raised concerns that patient care systems compromised patient safety and clinical outcomes. The backdrop for this interview was a front-page newspaper denial from senior executives within the health service that there were insufficient hospital beds to meet demand and it was publicly asserted that every patient was able to be admitted to a hospital bed:

Karen: last night for example ... I had thirty-two patients that I was responsible for [including a busy waiting room, with patients requiring admission] and no beds [no hospital beds available to admit sick patients who were in the department or waiting room]. And nobody could be transferred out because they're all ill. It's just the people in the waiting room that are my concern. You can have [patients with] chest pains out in the waiting room [potential heart attack victims]. We had a patient recently we brought from the waiting room into an office, [speaking here of needing a bed and having none available so an administrate office was used out of desperation] and he arrested [had a heart attack]. We had another critically ill patient in the Department for thirty-six hours. ... So in effect, I kind of see that as even a form of bullying, just this constant, being in-charge, and the constant nightmare of shifts (para 368).

In this instance, senior management created a public image which concealed actual adverse internal circumstances and procedures. The external façade of the organization was created in an image that coincided with industry standards and community expectations, while internally, contrary standards fostered unsafe practices. This behaviour sent a clear signal about what was considered acceptable conduct-meeting performance targets and maintaining the public image of the organization-regardless of the outcome.

Working in an environment where there was continued censorship apprehension was expressed by respondents that, raising concerns, rather than being seen as a legitimate attempt to right a wrong that was within the organization's power to rectify, they themselves would, instead, be framed as the problem. Speaking of this concern, it was recounted 'you knew your job was gone if you spoke out' (Susan, para 132). Confirming how silence was enforced in her work unit, Linda spoke of continued censorship and cover-up of misconduct. She recalled how a colleague in a position of authority targeted for dismissal an employee who had raised concerns about clinical errors and patient safety: 'the nurse who did nothing but identified the mistake was crucified. She lost her job because of that' (Linda, para 69).

In an institutional backdrop of silence and censorship, unethical behaviour was rationalized and even valorised, serving to sustain a spiral of deviance which permeated both institutions. As a result, bullying and other wrongdoing were denied and 'pushed underground only to flourish in the underside of organizational life' (Hart and Hazelgrove 2001: 257).

\section{Networks of "Predatory Alliances"}

The networks of informal alliances that existed between groups of individuals formed a central feature of the conduct that facilitated forms of bullying that could be considered 
corruption. Reported to us were powerful alliances that functioned to provide extensive opportunities for misconduct, providing the mechanism through which bullying as corruption proliferated and flourished. The type of bullying perpetrated within these alliances was not isolated acts of individuals; instead, it was a persistent, organised, clandestine, and systematic form of conduct, enabled through the relatively stable network of relationships between perpetrators. The predatory behavior involved numerous collaborative incidents, targeting multiple individuals over extended periods of time.

The alliances between those engaged in bullying were repeatedly portrayed by respondents as small groups bound by secrecy, agreed rules, and closeness. The alliances were described as: 'cliques' (Vanessa, para 162; Joan, para 185; Amanda, para 56), a 'cult' (Therese, para 156), the 'trifecta' or 'daily double' (Rowena, para 162), and an 'old girls club' (Therese, para 250). The alliances between bullies included relationships based upon family and social ties, places of training, or appointment and promotion. In the following passage, Grace speaks of the nature of the long-term relationships between individuals at a senior level within her workplace:

Grace: I think we've got some very incestuous relationships here in senior executive. I think it's very hard for people, particularly if they're outsiders that haven't grown up here, gone to school here, trained with everybody, worked with everybody for the last twenty, thirty years, all those people have moved up into higher positions. They've got a vested interest in keeping people where they are (Grace, para 374).

The enduring nature of these relationships was an important feature of the alliances, as the conduct described was a form of group behavior requiring the support of others also willing to engage in similar conduct. The full extent of alliances was not always known, or readily comprehended by targets, as the connections within alliances were often indiscernible to those targeted, as is the case with corruption networks (Nielsen 2003).

The structure of the networks reported to us comprised small, localized alliances, with junior actors supported by higher-ranking actors, resulting in a bullying hierarchy. Those higher-ranking were influential within the informal networks and were described respectively as the 'big' bully (Linda, para 197) or the 'gatekeeper' (Deborah, para 103). These individuals had appointment powers for significant and senior positions, and also functioned as 'boundary spanners' (Cross and Parker 2004: 77), providing critical links between the numerous smaller alliances across the organizations.

\section{Corrupting Legitimate Routines and Processes}

It was reported that power relations within the networks were used to corrupt legitimate processes, transforming opportunities derived from legitimate authority into personal gain. Working co-operatively, actors in the networks of alliances were able to co-opt legitimate organizational processes and procedures for the purpose of furthering their own interests and career opportunities and, in the process, cause considerable harm to others. If we consider a corrupt interaction to be one executed by way of a transfer of money or of power, that is, through the moneterization or bureaucratisation of social relations (Deflem 1995: 248), then individuals working together, using their power and legitimate authority inappropriately to bully others, is corruption.

Afforded protection through masking their behaviour within legitimate routines, actors in the alliances 'do what they like, write their own rules, and work together' (Susan, para 26) and, 'do things constantly that are not found out' (Helen, para 111). Helen, along with seven others working in four different departments provided repeated examples of bullies in 
their work teams acting together as a group, tolerating and hiding abusive behaviour, and providing an outward appearance of legitimacy and due process, while concurrently perpetrating extensive abuse on a number of targets. Respondents recounted meetings, convened behind a façade of legitimacy, which served as opportunities for abusive behaviour hidden from the view of others. Helen described how actors engaged in this form of bullying as corrupt activity employed revisionist history to conceal their actions:

Helen: I've seen the process of actually having three managers with you, that you're actually outnumbered. And they would actually change things. You know that wasn't said ... [their] behaviour was behind closed doors (para 46).

Other respondents recounted experiencing similar "meetings" that provided opportunities for unsubstantiated allegations about poor performance, threats, humiliation, and intimidation, with 'performance management' and 'disciplinary meetings' used to provide a cover of official legitimacy for the behaviour. Confident that their behaviour would not be disclosed, the alliances reportedly worked further and further outside of the realms of acceptable behaviour. In the following passage Helen, who had experienced escalating forms of bullying, revealed how her basic rights were denied:

Helen: I had to see the top clinical director, and I was really outnumbered then.

Researcher: What happened to bring you to the top Clinical Director?

Helen: I was just ordered to see her ... and I was just petrified. There was a directive and I thought, well, when people saw this person they did leave and everybody was terrified for me. It was like [Helen is visibly distressed and her voice falls away].

Researcher: Are you saying that when people went to see the person you were going to see, they left?

Helen: Yes. That's right. You're paid out. You were paid out... [Helen has been in tears] This is hard. Oh my God. Ok. I can see, that's right, I had been off sick and I was still in pain [following minor surgery] and I had one day off, and the manager said, "You are to see this particular person this afternoon". I said, "Look, really, I don't feel well. I feel quite ill." I said, "Can we make it another day"? And she said... "No, if it is necessary for you go to Casualty then you will interviewed on the bed"... I was so scared (Helen, para 126).

Participants reported alliances of bullies working in concert to harm targets through verbal abuse, isolation, harassment, threats and intimidation while, concurrently, denying targets access to justice and due process. As a result of this behavior, those targeted left the organization, cut back their working hours, or went on unscheduled leave as a result of the trauma they were experiencing. Wendy, Erica and Helen recounted witnessing the targeted destruction of Nurse Unit Managers in their work teams with the eventual result that those targeted resigned their positions, and those responsible for the bullying were appointed to the vacant positions by more senior members of the alliance who had the requisite appointment power.

On example recounted was that, during a period of restructure, individuals loyal to the alliances received appointments or promotions, while others lost their jobs. Those who raised concerns were told to 'shut their mouths' and told to 'watch my back because [names individual] was out to get me' (Susan, para 80). Organizational restructure and change processes were also reported to provide an opportunity for alliances to work together to abuse legitimate authority towards their own ends (see Hutchinson et al. 2005, 2006c). The 
behaviour of these bullies is a form of corruption. Respondents described, over and over, the dishonest use of official power, the dereliction of duty for personal gain, and conduct that deviated from formal rules (Lindgreen 2004).

These findings also reveal that bullying as corrupt conduct can be hidden within organizational routines and 'neutralized' (Coleman 1987: 14) making it appear normal or harmless. By working together in alliances, bullies were able to facilitate corrupt practices, bringing individuals together cooperatively for their mutual gain through established rules of reciprocity (Herbert 1998) that enabled continuation of their activities. Similar to other forms of misconduct or white-collar crime (Davies et al. 1999; Bennett and Robinson 2000), bullies described in this study were able to hide their activities within the context of normal routines and legitimate practices that they corrupted for their own purpose. As a result, the behaviour appeared acceptable, normal and routine, enabling it to escape detection as corruption or misconduct.

\section{Reward and Promotion}

The network of alliances between bullies provided extensive opportunities for co-operative, planned forms of bullying, as well as the mechanisms that rewarded the behaviour. The alliances operated to provide both the opportunity and motivation for personal gain, by enabling forms of unethical conduct through which individuals gained either network advantages within the alliances, improved personal status within the organizational hierarchy, or financial gain through increased income and retirement benefits. Respondents identified that when individuals who engage in corrupt conduct are promoted into management, in spite of their behaviour, corruption then becomes a tolerated means of ensuring personal "success"; it becomes normalized behaviour. Karen spoke of the frequency with which individuals with a history of misconduct were promoted:

Karen: And the interesting thing about [name of hospital] is that it seems, um, the worse you behave the more you seem to be rewarded [sarcastic laugh]. Like, you know, if you behave badly you get promoted (Karen, para 534).

Other respondents also detailed how relationships within the networks were established, or strengthened, through appointment and promotion, with those who participated in abusive and corrupt conduct frequently being rewarded with promotion. Deborah speaks of the nepotism that occurred during the appointment process:

Deborah: Yeah, well, what was interesting was, these managers [referring to two individuals who participated in her systematic abuse] who were also new managers got positions without qualifications. As there was a whole restructure, we had new managers, and half of these managers who got the jobs did not have management qualifications.

Social relationships and ties of loyalty within "alliances" of bullies were an important vehicle for career progression. Leonard (1985) studied the social relations among key decision makers within regional health planning agencies and reported that cliques reflected the organizational careers of individuals. The types of institutional relationships forged through promotion and reward in the network of alliances increased the propensity for individuals to engage in corrupt conduct.

A number of respondents detailed how individuals in their work teams, promoted to more senior positions by actors known to engage in bullying, began to increasingly participate in a range of predatory bullying activities, in conjunction with the manager responsible for their appointment. For example, Joan recounted being coerced into taking 
extended sick leave in response to what she considered to be falsified allegations of incompetence and psychiatric disturbance. While she was absent from her position, her portfolio of projects and grants - that had taken many years to develop — was divided up between her manager and others in her work team, improving their chances of promotion during a period of organization restructure while, at the same time, reducing Joan's chance of retaining her position. Joan recalled:

Joan: ... And my manager at work had organised for someone to replace me. And they wanted me off, wanted me to be on leave, they thought that I needed, they thought that I needed psychiatric help ... When this happened to me, the whole area was in a state of flux ... they were talking about amalgamating the department. They didn't know whether people were going to lose their jobs ... I had quite an extensive job before. While I hadn't been in it, they had given it to someone else ... By carving it all up [referring to the projects she managed that were given to others in the unit while she was on forced leave] people made sure they were doing something. One of the things I was running ...was actually given to the manager, the one who had me off work ... They had me out of my position so that they could carve up my role (Joan, para 13 and 103).

Here, the nexus between bullying, group anti-social behaviour, and the need for trust and networking aligns as the abuse of official power for personal gain - a recognized feature of corruption (Lindgreen 2004). In this instance, the alliance engineered the removal of a worker with relationships between individuals in the alliance providing what Ibarra (1992: 174) has termed 'protective coalition formation' which is defined as the systems of favours granted and owed, including mutual benefit and protection, and of connections invoked for the exercise of power (Ibarra 1992: 172). These served to mask, foster and condone the corrupt conduct.

\section{Protection from Detection}

Within the organizational authority structures and systems of both workplaces, mechanisms conducive to moral disengagement facilitated the abuse of institutional power for the purpose of protecting perpetrators in the alliances. Although both workplaces had high profile policies and procedures in place to manage bullying, numerous incidences were recalled where individuals, working together in alliances, were able to ensure legitimate reports of bullying were minimised, ignored and denied. It was reported this included the falsification of records or evidence as part of a deliberate and cooperative strategy for improving their own position and ensuring the continuation of their activities safely and in secret. As consequence, bullying was ignored, and those doing the bullying were protected 'by senior people' (Grace, para 234). Claire reported what happened after an internal investigation into serious reports of bullying:

Claire: There were five people named and the Director didn't want to upset these people... so nothing was ever done about it (Claire, para 58).

Further, it was recounted that the contact people responsible for investigating reports of bullying were known to have appointed and protected those engaged in bullying and, in some instances, were identified as a perpetrators of bullying. As a result, participants had little faith in the processes in place to manage bullying, especially reporting procedures and outcomes. They believed that making a report would make their work life even more difficult. Deborah shares this sentiment:

Deborah: To us, it's just a bit of paper [referring to the policy on bullying]. If you speak, there's retribution that is going to come back. So, you've got to figure out 
what's worth more to you. Officially, I know what my rights are. I can go to a counsellor or I can put in a report and document everything. But, she may get wrapped over the knuckles [speaking of her line manager], but then you cop it even more. It's happened before. It just causes people to leave, and I want to leave when I'm ready, not getting pushed (para 39).

Knowing that she was bullied by individuals who were "officially" protected by more senior members of a predatory alliance who "turned a blind eye" to her reports, Deborah believed she had no avenue for protection.

The control over the reporting process by bullies meant that activities of the alliances were kept hidden, or conducted in a manner that could be concealed. This was an important feature of the alliances as 'corruption's mode of expression is almost always covert' (Luo 2002: 204). Although the failure to respond to reports of bullying has been identified in previous research (Reeves 2000), the manner in which bullies were able to work together in these predatory and corrupt alliances to protect each other, and control the reporting process, has not previously been identified.

The protection afforded bullies through this behaviour resulted in bullies, with extensive histories of abuse and harm, bullying 'many different people' (Helen, para 60), being considered to 'pretty well run the show' (Joan, para 78), and being 'untouchable' (Deborah, para 10). Those interviewed recounted instances where misconduct was kept concealed and actors who spoke out were publicly discredited before various hearings, internal and external investigations (Lisa, para 61; Yvonne, para 308; Grace, para 334; Julie, para 223; Claire, para 123).

A further component ensuring protection within alliances was the mistreatment of those who had "blown the whistle". Grace recounted the consequences for those who "spoke out" against one bully, detailing the outcome of a formal investigation into a number of complaints: She said that the bully:

Grace: Just came out of it unscathed. The poor nurses that were involved in it [making reports that lead to the inquiry] were the ones that came off very poorly. I think that people [referring here to senior management] were protecting her [the perpetrator] because they were protecting themselves ... and she just got away with it. It was just amazing (para 248).

Following this investigation, in an organizational environment where an alliance of bullies controlled appointments, promotions, and the reporting processes, Grace and her colleagues knew their careers were destroyed and recalled feeling 'fairly powerless I think; the whole team was pretty powerless to do anything' (Grace, para 318).

It is known that corrupt group members can deny the moral validity of their violations and be entrusted with information without concern of this spreading to those outside the trusted corrupt group (Costello 1997: 408). Speaking of her experiences of trying to report what she considered corrupt conduct by her manager, Linda recounted how the confidential report she made about nepotism and 'clinical negligence' (para 12) was reported back to her manager by another senior manager in the organization. As a result, Linda's manager threatened her for making the report:

Linda: I have no faith in the system, that something would be done about it, at any level... And because of that, and you've got to also consider my relationship with my manager, and if I keep doing that, it puts me in a really difficult situation with my manager and then that, in turn, can actually make my life even worse. And why do that when you have no faith that it's going to help anything here at all? (para 108). 
Deliberately breaching Linda's confidentiality and not protecting her safety are corrupt activities. Controlling the flow of information within networks has been identified as an important feature of corrupt behaviour, with Coleman and Ramos (1998: 21) identifying that social relationships 'can serve as part of a network of communication that transmits information about opportunities' for corrupt activities, and ensures the corrupt conduct behaviour remains undisclosed.

Working together in this manner, the network of alliances functioned as "protective alarms" across the organizations. Individuals in the alliances sounded the "alarm" to others in the alliance when there was a risk of someone "blowing the whistle" or "blowing their cover" through disclosing their conduct. The "protective alarm" function of the alliances, evident in the passage from Linda, alerted actors in the predatory and corrupt alliances to the possibility of a breach in their network's secrecy and control over their activities. Such a warning ensured swift and brutal retaliation that silenced individuals who attempted to speak out about conduct deemed inappropriate or corrupt. These findings shed further light on the mechanisms through which those who blow the whistle end up with 'their careers and lives in tatters' (Johnstone 2004: 7).

\section{Discussion}

Our research has revealed that bullying can involve corruption with bullies misusing their organizational position for private power or political gain, while engaging in behaviour that deviates from formal rules of conduct while also protecting collaborators by failing to report misconduct to statutory authorities. Further, the protection and promotion of those within the corrupt and predatory alliances served to ensure their institutional and financial gain, through increased power, status, opportunities and income. These narratives reveal a form of unethical behaviour that required co-operation between several actors in the network. As a result of that co-operation, those in authority in were able to adapt the formal rules of office and subvert their obvious purpose, a feature of corruption in public sector organizations (Hindess 2004).

The bullying strategies depicted here, such as intimidation and verbal threats, have been extensively reported elsewhere in the bullying literature. However, we claim that new knowledge stems from our identification of the way those engaged in bullying work cooperatively together, in long lasting alliances within informal organizational networks that also enabled corrupt conduct. The misuse of positional power, the inappropriate use of organisational resources, and the channelling of status can all be considered corrupt activity. Similar to previous reports by Brass, Butterfield and Skaggs (1998), who examined the role of organizational networks and the spread of conspiracies, our study identified the manner in which close relationships within networks can foster unethical and corrupt conduct, while ensuring the protection necessary to ensure such behaviour remained undetected.

The relationships between actors in the alliances depicted by respondents served to perpetuate shared norms of professional morality tolerant of serious misconduct, regardless of the harm caused to individuals or the organisation. Professional networks do operate to filter out 'untrustworthy' actors (that is, those that don't share the acceptance of serious misconduct), and ensure solidarity, trust, and familiarity between those individuals who remain involved (Galaskiewicz 1985: 642). Through ensuring protection from detection as well as personal reward, the network of alliances provided the mechanism through which these deleterious norms of professional morality proliferated and flourished. Perversely, 
these shared norms also served to reinforce relationships of power within the networks, with bullies engaging in forms of misconduct deliberately, as a display of their protected position within the networks.

When corrupt behaviour spreads through an organization it is more likely to diffuse or routinize through superior-subordinate relationships (Pinto et al. 2008). Our study has shown that considerable individual power was gained through association with other more powerful actors in the networks. This 'reflected power' (Kanter 1993: 181) enabled lower level individuals to openly engage in bullying and corrupt acts knowing themselves to be protected by others more senior. By revealing the manner in which the networks of bullies operated together for extended periods of time, and functioned as a 'pervasive sub-system of corruption' (Nielsen 2003:125), our findings provide insight into the mechanisms for the contagion of bullying as corrupt conduct.

Further, our findings shed new light on the interplay between individual, environmental and organisational forces in the aetiology of bullying as corruption, drawing attention to the notion that it is no longer sufficient to locate and respond to bullying as conduct merely occurring at the individual or small group level. To date, almost all conceptualizations of workplace bullying have been limited to the examination of the behavior of individuals or small groups.

Additional research on workplace bullying may benefit from approaching the phenomenon as if one were approaching a very strong, secret, invisible network (Nielsen 2003: 126). This expanded understanding of workplace bullying should include acknowledgement of corrupt conduct within groups, organizations, or even industry sectors, and will enable organisations to recognise the seriousness of what is happening in their organisations and respond accordingly.

The interview material reported provides a vivid insight into how corrupt norms were established and perpetuated within the broader context of the politicisation of the public sector. In such an organizational context, senior staff in the hierarchy went to great lengths to ensure that the reality of organizational life was never made public, thereby maintaining a positive "spin" on publicly disclosed details. There was evidence that those more senior within the workplaces who "turned a blind eye" and hid events from the public for political gain, would also "turn a blind eye" to corrupt conduct to prevent risking public exposure of the organisation and individual's concerned.

Corrupt systems are self-perpetuating and self-protective, and they are apt to persecute or isolate people, particularly those who seek to make change (Waite and Allen 2003). Climates of silence corruption perpetuate opportunities for institutions to marginalise, shun and vilify those who "speak out" (Faunces and Bolsin 2004). To date, there has been scant investigation into the act of whistleblowing in the health care sector (Jackson 2008). Little is understood about the dilemmas and difficulties health care workers face in deciding to take this course of action. To date, cover-ups of adverse events have been understood as a conspiracy of silence, or a form of cultural censorship, where rule breaking is tacitly accepted as an inevitable part of the way doctors and nurses learn to work together (Hart and Hazelgrove 2001: 261). Our study demonstrates alternative explanations of these forms of silence. By analysing the experiences of nurses through the lens of corruption, it has been possible to demonstrate the ability of networked actors to shape institutional cultures in ways that advantage them personally (Phillips 2003). Understanding the perpetuation of bullying behaviours in this way has important implications for the future management of workplace bullying, aggression, and other forms of organisational mistreatment and misconduct, as well as the means through which adverse events are managed within the sector. 


\section{Conclusion}

Recently, Pinto et al. (2008) noted that sparse attention has been directed towards understanding forms of corruption that benefit individuals who engage in collusion between organizational members. Our data suggests that networked relationships among individuals across organizations can influence the presence and nature of bullying and, in particular, bullying as a form of corrupt conduct. The identification of these relationships and the mechanisms through which corrupt conduct proliferates, suggest that consideration needs to be given to the characteristics of individual actors, organizational sub-cultures, and social networks within organizations, to further understand workplace bullying and the harmful consequences it can have for both individuals and organizations. The narratives reported here highlight the importance of the moral dimension of bullying and corruption. Importantly, our findings also shed light on what happens in institutions where corrupt conduct though bullying becomes a form of institutionalized, habituated behaviour that goes formally unrecognised and unchecked.

Many of the behaviours cited in this research are clearly forms of corrupt conduct, where individuals misused their position and their access to organisational resources for personal power and political gain. These abuses of position and authority clearly deviate from the formal rules of conduct in place (Lindgreen 2004). Previous research has identified the manner in which cliques operate to facilitate fraud and embezzlement (Nohria and Eccles 1992), and that business crimes require relationships of trust that permit the activity (Granovetter 1992). This study also highlights how cliques facilitate forms of professional misconduct that, through the misuse of promotion and political gain within the organisation, also serve as a financial incentive for those involved.

Further research is required to explore the manner in which the ethical environment of an organization may influence workplace bullying, especially when this includes corrupt conduct. Importantly, within the health sector, further research might usefully explore how industry and institutional culture, norms or ethics, influence the types of behaviour reported in this study. Of concern to those in the health industry should be the finding that both organizations participating in this study had a degree of dependence on the corrupt norms embedded within the networks of alliances (Ackroyd and Thompson 1999). Of further concern was the apparent inability of those organisations to constrain the behaviour when it was identified, or even make it visible.

The purpose of this paper has been to depict that much of bullying is corrupt conduct; a notion that has, to date, received no attention in the literature. We have focused attention on informal organizational networks and their role in facilitating such behaviour. The extent and nature of this conduct is an important issue. In health care organizations in particular, the ethical implications and the potential harm that flows from such behaviour, requires urgent examination.

\section{References}

Ackroyd, S., \& Thompson, P. (1999). Organizational misbehavior. London: Sage Publications.

Afsana, K. (2004). The tremendous cost of seeking hospital obstetric care in Bangladesh. Reproductive Health Matters, 12(24), 171-180.

Ashforth, B. E., \& Anand, V. (2003). The normalization of corruption within organizations. Research in Organizational Behavior, 25, 1-52.

Ashforth, B. E., Gioia, D. A., Robinson, S. L., \& Trevino, L. K. (2008). Re-viewing organizational corruption. The Academy of Management Review, 33(3), 670-684. 
Bandura, A. (2002). Selective moral disengagement in the exercise of moral agency. Journal of Moral Education, 31(2), 101-119.

Bennett, R. J., \& Robinson, S. L. (2000). The past, present and future of workplace deviance research. In J. Greenberg (Ed.), Organizational behavior: The state of the science (pp. 247-282, 2nd ed.). NJ: Erlbaum.

Brass, D. J., Butterfield, K. D., \& Skaggs, B. C. (1998). Relationships and unethical behavior: A social network perspective. The Academy Of Management Review, 23(1), 14-31.

Bukovansky, M. (2002). Corruption is bad: Normative dimensions of the anti-corruption movement. Canberra: Australian National University.

Chang, J. J., \& Lai, C. C. (2002). Is the efficiency wage efficient? The social norm and organizational corruption. Scandinavian Journal of Economics, 104, 24-47.

Chappell, D., \& Di Martino, V. (2000). Violence at work (2nd ed.). International Labour Office: Geneva.

Coleman, W. J. (1987). Toward an integrated theory of white collar crime. American Journal of Sociology, 93, 406-439.

Coleman, W. J., \& Ramos, L. L. (1998). Subcultures and deviant behaviour in the organizational context. In P. A. Bamburger, \& W. J. Sonnestohl (Eds.), Research in the sociology of organisations: Deviance in and of organizations (pp. 3-31). Stamford, Connecticut: JAI.

Costello, B. (1997). On the logical adequacy of cultural deviance theories. Theoretical Criminology, 1, 402-428.

Cresswell, J., Fetters, A., \& Ivankova, N. (2004). Designing a mixed method study in primary care. Annals of Family Medicine, 2(1), 7-12.

Cross, R., \& Parker, A. (2004). The hidden power of social networks: Understanding how work really gets done in organizations. Boston, Massachusetts: Harvard Business School.

Davies, P., Francis, P., \& Jupp, V. (1999). The features of invisible crimes. In P. Davies, P. Francis, \& V. Jupp (Eds.), Invisible crimes: Their victims and their regulation (pp. 3-28). London: MacMillan.

Deflem, M. (1995). Corruption, law, and justice: A conceptual clarification. Journal of Criminal Justice, 23 (3), 243-258.

Dowden, C., \& Tellier, C. (2004). Predicting work-related stress in correctional officers: A meta-analysis. Journal of Criminal Justice, 32, 31-47.

Einarsen, S. (1999). The nature and causes of bullying at work. International Journal of Manpower, 20(1/2), $16-27$.

Einarsen, S. E., Hoel, H., Zapf, D., \& Cooper, C. L. (2003). The concept of bullying at work: The European tradition. In S. E. Einarsen, H. Hoel, D. Zapf, \& C. L. Cooper (Eds.), Bullying and emotional abuse in the workplace. International perspectives in research and practice (pp. 3-30). London: Taylor \& Francis.

Ensor, T. (2004). Informal payments for health care in transition economies. Social Science and Medicine, $58,237-246$.

Faunces, T. A., \& Bolsin, N. C. (2004). Three Australian whistleblowing sagas: Lessons for internal and external regulation. The Medical Journal of Australia, 181(1), 44-47.

Frank, B., \& Schulze, G. G. (2000). Does economics make citizens corrupt? Journal of Economic Behavior and Organization, 43, 101-113.

Galaskiewicz, J. (1985). Professional networks and the institutionalization of a single mind set. American Sociological Review, 50, 639-658.

Granovetter, M. (1992). Problems of explanation in economic sociology. In N. Nohria, \& R. G. Eccles (Eds.), Networks and organizations: Structure, form and action (pp. 25-56). Massachusetts: Harvard Business School Press.

Griffin, L. (2005). Watch out for whistleblowers. The Journal of Law Medicine and Ethics, 33(1), 160-163.

Hart, E., \& Hazelgrove, J. (2001). Understanding the organizational context for adverse events in the health services: The role of cultural censorship. 10, 257-262.

Herbert, S. (1998). Police subculture reconsidered. Criminology, 36, 343-369.

Heyneman, S. P. (2004). Education and corruption. International Journal of Educational Development, 24, 637-648.

Hindess, B. (2004). Corruption and democracy in Australia. Canberra: Australian National University.

Hubert, A. B., \& van Veldhoven, M. (2001). Risk sectors for undesirable behavior and mobbing. European Journal of Work and Organizational Psychology, 10(4), 415-424.

Hutchinson, M., Vickers, M., Jackson, D., \& Wilkes, L. (2005). "I'm gonna do what I wanna do!": Organizational change as a legitimized vehicle for bullies. Health Care Management Review, 30(4), 331-338.

Hutchinson, M., Vickers, M. H., Jackson, D., \& Wilkes, L. (2006a). Workplace bullying in nursing: Towards a more critical organizational perspective. Nursing Inquiry, 13(2), 118-126.

Hutchinson, M., Vickers, M. H., Jackson, D., \& Wilkes, L. (2006b). "Like wolves in a pack": Stories of predatory alliances of bullies in nursing. Journal of Management and Organization, 12(3), 235-251.

Hutchinson, M., Vickers, M., Jackson, D., \& Wilkes, L. (2006c). They stand you in a corner; you are not to speak: Nurses tell of abusive indoctrination in work teams dominated by bullies. Contemporary Nurse, 21(2), 228-238. 
Hutchinson, M., Vickers, M., Jackson, D., \& Wilkes, L. (2008). A new model of bullying in the nursing workplace: Organizational characteristics as critical antecedents. Advances in Nursing Science, 31(2), E 6-71.

Ibarra, H. (1992). Structural alignments, individual strategies, and managerial action: Elements toward a network theory of getting things done. In N. Nohria, \& R. G. Eccles (Eds.), Networks and organizations: Structure, form and action (pp. 164-188). Massachusetts: Harvard Business School Press.

Ibrahim, J., \& Majoor, J. (2002). Corruption in the health care system: The circumstantial evidence. Australian Health Review, 25(2), 20-26.

Jackson, D. (2008). Editorial: What becomes of whistleblowers? Journal of Clinical Nursing, 17(10), 12611262.

Johnstone, M. J. (2004). Quality, safety and scandal: Are we learning the hard way from events at Campbelltown and Camden hospitals? Australian Health Review, 28(1), 7-19.

Kanter, R. M. (1993). Men and women of the corporation (Preface and afterword 1993 to the 1977 edition). New York: Basic.

Kivimäkia, M., \& Virtanen, M. (2003). Workplace bullying and the risk of cardiovascular disease and depression. Occupational and Environmental Medicine, 60(10), 779-783.

Kriekebaum, H. (2008). Corruption as a moral issue. Social Responsibility Journal, 4(1/2), 82-88.

Lambsdorff, J. G. (2002). Making corrupt deals: Contracting in the shadow of the law. Journal of Economic Behaviour and Organization, 48, 221-241.

Langbein, L., \& Jorstad, C. (2004). Productivity in the workplace: Cops, culture, communication, and collusion. Political Research Quarterly, 57, 65-79.

Lange, D. (2008). A multidimensional conceptualization of organizational corruption. The Academy of Management Review, 33(3), 710-729.

Leonard, F. (1985). Clique formation in a regional health planning agency. Human Relations, 38(9), 895-911.

Leymann, H. (1996). The content and development of mobbing at work. European Journal of Work and Organizational Psychology, 5, 165-184.

Lincoln, Y., \& Guba, E. G. (1985). Naturalistic inquiry. Newbury Park, California: Sage Publications.

Lindgreen, A. (2004). Corruption and unethical behavior: Report on a set of Danish guidelines. Journal of Business Ethics, 51(1), 31-36.

Luo, Y. (2002). Corruption and organization in Asian management systems. Asia Pacific Journal of Management, 19(2), 405-428.

Marjit, S., \& Shi, H. (1998). On controlling crime with corrupt officials. Journal of Economic Behavior and Organization, 34, 163-172.

McCarthy, P., Sheehan, M., \& Kearns, D. (Eds.) (1995). Managerial styles and their effects on employees health and well-being in organizations undergoing restructuring. Brisbane: School of Organizational Behavior and Human Resource Management, Faculty of Commerce and Administration, Griffith University. Brisbane, Australia.

McCormack, R. J. (1996). Police perceptions and the norming of institutional corruption. Policing and Society, 6, 239-246.

McKay, R., Huberman Arnold, D., Fratzl, J., \& Thomas, R. (2008). Workplace bullying in academia: A Canadian study. Journal Employee Responsibilities and Rights Journal, 20(2), 77-100.

Miles, M., \& Hubermann, M. (1994). Qualitative data analysis: An expanded sourcebook. Thousand Oaks, California: Sage Publications.

Misangyi, V. F., Weaver, G. R., \& Elms, H. (2008). Ending corruption: The interplay among institutional logics, resources, and institutional entrepreneurs. Academy of Management Review, 33(3), 750-770.

Nielsen, R. P. (2003). Corruption networks and implications for ethical corruption reform. Journal of Business Ethics, 42(2), 125.

Nohria, N., \& Eccles, R. G. (1992). Face-to-face: Making network organizations work. In N. Nohria, \& R. G. Eccles (Eds.), Networks and organizations: Structure, form and action (pp. 288-308). Massachusetts: Harvard Business School Press.

Olivier de Sardan, J. P. (1999). A moral economy of corruption in Africa? Journal of Modern African Studies, 37(1), 25-52.

O’Moore, M., Lynch, J., \& Daeid, N. N. (2003). The rates and relative risks of workplace bullying in Ireland, a country of high economic growth. International Journal of Management and Decision Making, 4(1), 82-95.

Phillips, N. (2003). Power and institutions. In R. Westwood, \& S. Clegg (Eds.), Debating organization: Point-counterpoint in organizational studies (pp. 201-231). Malden, USA: Blackwell.

Pinto, J., Leana, C. R., \& Pil, F. K. (2008). Corrupt organizations or organizations of corrupt individuals? Two types of organization-level corruption. Academy of Management Review, 33(3), 685-709.

Pitt, L. F., \& Abratt, R. (1986). Corruption in business - are management attitudes right? Journal of Business Ethics, 5(1), 39-45. 
Reeves, M. (2000). Suppressed, forced out and fired: How successful women lose their jobs. Westport, Connecticut: Quorum.

Reich, M. R. (2002). Reshaping the state from above, from within, from below: Implications for public health. Social Science and Medicine, 54, 1669-1675.

Robbins, P. (2000). The rotten institution: Corruption in natural resource management. Political Geography, $19,423-443$.

Robinson, S. L., \& O’Leary-Kelly, A. M. (1998). Monkey see, monkey do: The influence of work groups on the antisocial behaviour of employees. Academy of Management Journal, 41(6), 658-671.

Salin, D. (2003). Ways of explaining workplace bullying: A review of enabling, motivating and precipitating structures and processes in the work environment. Human Relations, 56(10), 1213-1220.

Shields, M., \& Wilkins, K. (2006). Findings from the 2005 national survey of the work and health of nurses. Ottawa, Canada: Health Canada and Canadian Institute for Health Informatics.

Simpson, R., \& Cohen, C. (2004). Dangerous work: The gendered nature of bullying in the context of higher education. Gender Work and Organization, 11(2), 163-186.

Sissener, T. K. (2001). Anthological perspectives on corruption. Bergen, Norway: Chr. Mechelsen Institute.

Stevenson, K., Randle, J., \& Grayling, I. (2006). Inter-group conflict in health care: UK students experiences of bullying and the need for organizational solutions. The Online Journal of Issues in Nursing Retrieved November 3rd, 2006 from www.nursingworld.org/ojin/topic30/tpc30_5.htm.

Vickers, M. H. (2006). Towards employee wellness: Rethinking bullying paradoxes and masks. Employee Responsibilities and Rights Journal, 18, 267-281.

Waite, D. G., \& Allen, D. (2003). Corruption and abuse of power in educational administration. The Urban Review, 35(4), 281-296.

Zapf, D., \& Einarsen, S. (2003). Individual antecedents of bullying: Victims and perpetrators. In S. E. Einarsen, H. Hoel, D. Zapf, \& C. C. L. (Eds.), Bullying and emotional abuse in the workplace: International perspectives in research and practice (pp. 165-184). London: Taylor \& Francis. 